\title{
The Effect of Gender Diversification in Top Management and Intellectual Capital on the Company's Financial Performance and Its Impact on Firm Value
}

\author{
Anisya*, Yudhi Herliansyah \\ Mercu Buana University Jakarta, Jl. Raya, RT.4/RW.1, Meruya Sel., Kec. Kembangan, Jakarta, Daerah Khusus Ibukota Jakarta 11650, Indonesia
}

DOI: $10.36348 /$ sjef.2020.v04i12.008

| Received: 27.11.2020 | Accepted: 09.12.2020 | Published: 26.12.2020

*Corresponding author: Anisya

\section{Abstract}

This study analyzes the effect of gender diversification in top management and intellectual capital on financial performance proxied by ROA and its impact on firm value in the financial sector listed on the Indonesia Stock Exchange in 2017-2018. This study uses secondary data from the company's annual reports which are taken from the official website of the Indonesia Stock Exchange and the company's official website. The number of companies studied was 87 out of 99 companies with purposive sampling and observations made were for 2017 to 2018 so that the total number of observations was 174 samples. Data were analyzed using path analysis with the SPSS application.

Keywords: Gender Diversification, Intellectual Capital, Financial Performance, ROA, Firm Value.

Copyright (C) 2020 The Author(s): This is an open-access article distributed under the terms of the Creative Commons Attribution 4.0 International License (CC BY-NC 4.0) which permits unrestricted use, distribution, and reproduction in any medium for non-commercial use provided the original author and source are credited.

\section{INTRODUCTION}

The value of a company is often interpreted as market value, profit or prosperity which is the goal of shareholders which can be maximized if the market value increases, the many factors that affect firm value make the study of firm value still interesting to study. Directors have an important role in a company, so with gender diversification in the board of directors will provide a positive signal to internal and external parties of the company. The presence of women in top management will increase diversity in terms of gender which is thought to have a positive impact on the company. The greater diversity in top management can lead to broader discussion and richer alternatives for decision making, and can consider a more comprehensive set of solutions.

Many women in Indonesia have positions in top management, this can happen because Indonesian companies are one that is friendly to women, as evidenced by the results of a survey by global firm Grant Thornton entitled "Women in Business 2018" of 5,000 respondents in top management levels, the presence of women in Indonesia, it is the largest in the world and exceeds the average in the Asia Pacific region, this shows that there is a phenomenon of an increasing number of women in top management such as boards of commissioners or directors in the modern business world.
It is hoped that the presence of women in top management will not only improve the task performance of the top management team itself but also increase the motivation and commitment of women at lower managerial levels as well as encourage the adoption of behaviors associated with feminine management styles, which in the future can improve individual task performance and groups across the company, which will enhance the company's financial performance and value.

With the development of technology, it encourages the emergence of a "new economy" and makes interest in intellectual capital grow [1,2]. The term intellectual capital emphasizes the combination of intellectuality and capital to show the importance of knowledge [3]. Many companies in Indonesia still apply conventional based in running their business, this makes the products they produce do not have a high technological content, but it is different from companies in the financial sector that have begun to utilize the latest technology in their business processes.

\section{THEORETICAL BASIS \& LITERATURE REVIEW \\ Stereotype Theory}

Stereotypes give perceptions to the attitudes of women and men about how to face and determine the right solution to a problem, the decision-making 
process, the creation of ideas that can develop the company and in terms of leadership styles that will have an impact on the performance of a company.

\section{Trait Leadership Theory}

Trait leadership theory focuses on the characteristics of a leader which is used to see how effective a person's leadership is.Based on the theory of trait leadership, both men and women can have characteristics as leaders. From the leadership trait theory, it can be concluded that the existence of gender diversification in top management or the board of directors will affect financial performance because there are differences in leadership traits between women and men which are expected to have a better way of making decisions than homogeneous ones.

\section{Resources Based Theory (RBT)}

RBT is a theory that would be appropriate in explaining intellectual capital because it focuses on the competitive advantage of a company through its resources and its relationship to performance, Belkaoui [4] states that the high intellectual capital or ability of a company will be highly valued by investors.

\section{Signaling Theory}

Signaling Theory states that the company will give a positive signal to the market if they have an advantage. Meanwhile, companies that lack a competitive advantage will give signals or information that are mandatory [3].

\section{Gender Diversification}

Gender is a concept used to identify differences between men and women from a sociocultural perspective [5]. There are two perspectives that explain the existence of women on company boards, namely arguments from a business perspective and arguments from a moral perspective. These two arguments are divided into two, namely arguments for equality or equality of opportunity and arguments for equality or equality of representation. The business perspective regarding the equal opportunity argument for women focuses on the fact that the presence of women on company boards is suboptimal for the company [6].

\section{Intellectual Capital}

The term intellectual capital emphasizes the combination of intellectuality and capital to show the importance of knowledge [7] is a resource that becomes the capital for the organization to win the competition.

\section{Firm Value}

Firm value is often defined as the market value, profit or prosperity that shareholders aim to maximize if the market value increases. High stock capitalization shows that investors' perceptions of a company are also high, therefore Tobin's Q is used as a reference because it accommodates all elements to calculate the company's value, not only market value or book value but include both.

\section{Company Financial Performance}

The company's financial performance can be seen from the financial statements. This financial report is prepared and interpreted for the benefit of management and other parties who have an interest in or have an interest in company financial data [8].

\section{The Effect of Gender Diversification on Company Financial Performance}

The careful and detailed characteristics inherent in women generally make it more optimal to use available information in solving problems in the company compared to men who do not maximize information, this certainly affects the decision-making made by women and men whose decisions can be made affect the company's financial performance, and by adding a woman to an all-male top management team as well to improve team task performance. Better task performance by the top management team, will lead directly to better company performance.

Some researchers suggest that companies should increase the presence of women on their boards, as this has a positive effect on business performance [9]. Better economic performance will result in new ideas, skills and different perspectives that come from greater board diversification [9]. Irean Yap Lee-Kuen et al., [10] found that a higher level of women's representation on the board improves the financial performance of companies in Malaysia.

$\mathrm{H}_{1}$ : Gender diversification has a positive effect on the company's financial performance.

\section{The Effect of Intellectual Capital on Company Financial Performance}

It is hoped that the financial performance will get better if the intellectual capital owned by the company can be utilized and managed properly. Research by Riahi-Belkaoui [11] in his research concluded that there is a positive relationship between intellectual capital and financial performance, while Bontis et al., [12] found that structural capital development has a positive impact on business performance. Solikhah [13] proved that intellectual capital has a positive effect on financial performance and growth. Good management of intellectual capital will give the company a competitive advantage to enter into business competition, with good management and this competitive advantage will improve the company's financial performance.

$\mathrm{H}_{2}$ : Intellectual capital has a positive effect on the company's financial performance

\section{Effect of Gender Diversification on Firm Value}

The presence of female members in top management in a company will give a positive signal to internal and external parties of the company. High 
diversity indicates that there is no limit for a woman to enter the top management of the company regardless of their demographic characteristics, so that both men and women can have the same opportunity to be in top management.

The presence of women in top management indicates that the company does not discriminate gender in terms of career opportunities, which in turn will increase the reputation (legitimacy) and value of the company [14].

$\mathrm{H}_{3}$ : Gender diversification has a positive effect on firm value

\section{The Effect of intellectual capital on the value of the company}

Value creation is basically the goal of all activities that run in a company, with this value creation makes a company better in meeting the interests of its stakeholders. In terms of Intellectual Capital, this value creation is done by maximizing the use of Intellectual Capital elements, namely human capital, physical capital, and structural capital. It is better to maximize Intellectual Capital, the better the company will be in the eyes of stakeholders and will increase the company's value

$\mathrm{H}_{4}$ : Intellectual capital has a positive effect on firm value

\section{Effect of Financial Performance on Firm Value}

Financial performance is an indicator of the health of a company, the better the financial performance of a company can reflect the good management that has been carried out by the company's management.

The ratio of return on assets (ROA) can be a tool to measure the level of efficiency and effectiveness of a company's financial performance. A good company's financial performance will have an impact on increasing the value of a company.

Company value is a benchmark for investors in making investment decisions, the higher the company value, the more investors will be interested in investing in the company and of course it will affect the company's financial performance.

Muliani [15] in his research proved that financial performance has a significant effect on firm value. Halimah's research [16] also states that financial performance as measured by ROA has a significant effect on the value of a company.

$\mathrm{H}_{5}$ : Financial performance has a positive effect on firm value

\section{Effect of Gender Diversification on Firm Value with Financial Performance as an Intervening Variable}

Kusumastuti et al., [5] in their research stated that one of the attitudes of women is to avoid risk because they tend to be more careful and conscientious than men. This makes them less likely to be careless when it comes to decision making. Therefore, the existence of women in top management who act as decision makers will be able to assist in making business decisions that are lower risk and more precise which in turn are expected to improve financial performance and company value.

Research by Smith et al., [17] states that the positive effect of having the proportion of women in top management still depends on the qualifications of these managers. Carter [18] and Siciliano [19] prove that gender diversification has a positive effect on firm performance.

Irean Yap Lee-Kuen et al., [10] found that a higher level of women's representation on the board improves the financial performance of companies in Malaysia. Gordini and Rancati [20] found that gender diversification on the board has a significant effect on the company's financial performance.

$\mathrm{H}_{6}$ : Gender diversification has a positive effect on firm value with financial performance as an intervening variable

\section{The Effect of Intellectual Capital on Firm Value with Financial Performance as an Intervening Variable}

The resource-based RBT theory assumes that a company will have a competitive opportunity if the company can manage all its resources effectively and efficiently and is supported by a good intellectual ability of the company which will encourage an increase in company performance can attract investors so that the company's value will be even better.

Belkaoui [4] states firmly that if the market has reached an efficient condition, investors will give high value to companies that have higher Intellecutal Capital. In addition, if intellectual capital is a measurable resource for increasing competitive advantage, it will contribute to the company's financial performance and increase firm value [21]. Bontis et al., [12] in his research concluded that, regardless of industry, structural capital development has a positive impact on business performance. Then if the financial performance is good, the company value will also be good.

$\mathrm{H}_{7}$ : Intellectual capital has a positive effect on firm value with financial performance as an intervening variable

\section{RESEARCH METHODOLOGY}

This study uses secondary data taken from the official IDX website and the company's official website, using purposive sampling to determine the sample, with criteria 1) Financial sector companies listed on the Indonesia Stock Exchange (IDX) consecutively during the 2017-2018 period. 2) The company published 
consecutive annual reports during the 2017-2018 period. 3) The company published consecutive audited financial statements for the 2017-2018 period using the financial year ended December 31. 4) There are successive data completeness during the 2017-2018 period in the annual report needed in the research.

This study uses 3 (three) variables, namely the dependent variable, the independent variable, and the intervening variable.

\section{1) Dependent Variable}

The dependent variable in this study is Firm Value as measured using Tobin's Q, formulated as follows:

$$
\text { TOBIN'S Q }=\frac{\text { MARKET VALUE }+ \text { DEBT }}{\text { TOTAL ASSET }}
$$

\section{2) Intervening Variables}

In this study, financial performance is used as an intervening variable. In this study, financial performance uses a proxy for profitability as measured by ROA [21]. ROA is calculated by the formula:

$$
\text { ROA }=\frac{\text { NETT PROFIT }}{\text { TOTAL ASSET }}
$$

\section{3) Independent Variable}

In this study, what is used as an independent variable is gender diversification as measured by the Blau's Index introduced by Blau [22] and has been used by several researchers, such as the research of Irean Yap Lee-Kuen et al., [10] and I Wayan Teg Teg [23]. The next independent variable is intellectual capital (IC) as measured by Modified VAIC (MVAIC) [3].

\section{Path Analysis}

The stages of using path analysis to complete this research are [24]:

1. Make a path diagram model based on the relationship between variables.

2. Creating Structural Equations

This study has two structural equations as below:

$\mathrm{Y} 1=\mathrm{PY} 1 \mathrm{X} 1+\mathrm{PY} 1 \mathrm{X} 2+\mathrm{e} 1$

(substructural equation I)

$\mathrm{Y} 2=\mathrm{PY} 2 \mathrm{X} 1+\mathrm{PY} 2 \mathrm{X} 2+\mathrm{PY} 2 \mathrm{Y} 1+\mathrm{e} 2$

(substructural equation II)

3. Analyze into SPSS.

The analysis consists of two steps, namely for substructural I and substructural II.

\section{Intervening Variable Analysis}

To test the analysis of the mediating or intervening variables in this study, the causal step method was developed by Baron and Kenny [25]. As for the steps in using the Causal Step Method:

First, Creating a regression equation for Gender Diversification (X1) and Intellectual Capital (X2) on Firm Value (Y2).

Second, create a regression equation for Gender Diversification (X1) and Intellectual Capital (X2) on Financial Performance (Y1).

Third, create a regression equation for Gender Diversification (X1), Intellectual Capital (X2), Financial Performance (Y1).

Testing Criteria [26]:

First, a mediating variable will be considered a perfect mediation variable if after entering the Mediation variable, the effect of variable X on Y which was significant (before entering the Mediation variable) becomes insignificant after entering the Mediation variable into the regression equation model.

Second, a mediation variable is stated as a partial mediation variable if after entering the Mediation variable, the effect of variable $\mathrm{X}$ on $\mathrm{Y}$ which was significant (before entering the Mediation variable) remains significant after entering the Mediation variable into the regression equation model, but decreased regression coefficient.

\section{RESULT AND CONCLUSION}

\begin{tabular}{|c|c|c|c|c|c|c|}
\hline \multicolumn{7}{|c|}{ Coefficients $^{\mathrm{a}}$} \\
\hline \multirow{2}{*}{\multicolumn{2}{|c|}{ Model }} & \multicolumn{2}{|c|}{ Unstandardized Coefficients } & \multirow{2}{*}{$\begin{array}{l}\text { Standardized Coefficients } \\
\text { Beta }\end{array}$} & \multirow[t]{2}{*}{$\mathrm{t}$} & \multirow[t]{2}{*}{ Sig. } \\
\hline & & $\mathrm{B}$ & Std. Error & & & \\
\hline \multirow[t]{3}{*}{1} & (Constant) & -0.019 & 0.006 & & -3.373 & 0.001 \\
\hline & Gender Diversification & 0.016 & 0.012 & 0.102 & 1.372 & 0.172 \\
\hline & Intellectual Capital & 0.013 & 0.002 & 0.541 & 7.296 & 0 \\
\hline
\end{tabular}

Table-1: Substructural I (Hypothesis 1-2)

\section{The Effect of Gender Diversification on Financial Performance}

The results of the analysis show that gender diversification at the top management has no significant effect on financial performance as proxied by ROA.
This result is not in accordance with hypothesis 1 which states that gender diversification has a positive effect on financial performance. This result is also not in line with the stereotype theory and leadership theory which is the basis of this research. Stereotype theory and 
leadership theory say the presence of women is said to lead to sensitive behavior towards other perspectives, as well as a more interactive and transformational management style [27], which can lead to improved corporate governance through more open-ended questions and discussions [28].

However, even so, the proportion of top management of women in public companies in Indonesia is still very small compared to male top management, especially in companies that are the sample in this study which are also public companies, because in Indonesia the position of women on the board of directors is generally still This is due to family factors and occurs in small companies [29] so that the effect of Gender Diversification which in this case is also measured by the proportion of women in top management is insignificant, apart from being too small a proportion of women as well because currently working women are generally not significant can be said to be more resilient and highly educated, which causes their thinking patterns to almost match men in decision making who rely more on logic than on their sensitivity or cognitive feelings so that strategic decision making according to stereotype theory and leadership theory can run better if greater Gender Diversification is not proven.

Another reason is that women dislike or avoid financial risks than men. It can also be possible to influence the company's financial performance, other factors such as the type of company industry that is the object of this research are also possible to influence research results, the financial industry may not really need a view of feelings. women's cognitive which is their strength, it is different if in the beauty or fashion industry which allows women's views to be the basis for making business decisions that affect performance.

\section{The Effect of Intellectual Capital on Financial Performance}

The results of the analysis show that intellectual capital has a significant effect on financial performance, which is proxied by ROA. This result is in accordance with hypothesis 2 which states that intellectual capital has a positive effect on financial performance. This result is also in line with RiahiBelkaoui's [11] research which concluded that there is a positive relationship between intellectual capital and financial performance, while Bontis et al., [12] found that structural capital development has a positive impact on business performance. Solikhah [13] proved that intellectual capital has a positive effect on financial performance and growth. By managing good intellectual capital, a company will have a competitive advantage to enter business competition with good management and competitive advantage will improve the company's financial performance. This is in line with the concept of Resources Based Theory (RBT). Resources Based Theory (RBT) also states that a company will have a competitive advantage if its resources are superior and not owned by other companies [30].

Table-2: Substructural II (Hyphotesis 3-7)

\begin{tabular}{|c|c|c|c|c|c|c|}
\hline \multicolumn{7}{|c|}{ Coefficients $^{\mathrm{a}}$} \\
\hline \multirow{2}{*}{\multicolumn{2}{|c|}{ Model }} & \multicolumn{2}{|c|}{ Unstandardized Coefficients } & \multirow{2}{*}{$\begin{array}{l}\text { Standardized Coefficients } \\
\text { Beta }\end{array}$} & \multirow[t]{2}{*}{$\mathrm{T}$} & \multirow[t]{2}{*}{ Sig. } \\
\hline & & $\mathrm{B}$ & Std. Error & & & \\
\hline \multirow[t]{4}{*}{1} & (Constant) & .868 & .070 & & 12.410 & .000 \\
\hline & Gender Diversification & .069 & .142 & .039 & .482 & .630 \\
\hline & Intellectual Capital & .060 & .026 & .219 & 2.265 & .025 \\
\hline & Financial Performance & 2.938 & 1.079 & .265 & 2.722 & .007 \\
\hline
\end{tabular}

\section{Effect of Gender Diversification on Firm Value}

The results of the analysis show that the gender diversification of the board of directors has an insignificant effect on firm value as measured by Tobin's Q. This result is not consistent with hypothesis 3 which states that gender diversification has a positive effect on firm value. This result is also not in line with the stereotype theory and leadership theory which is the basis of this research. This insignificant effect is probably due to the absence of differences in performance between men and women. The gender diversification that appears in the top management ranks may be easier to explain from a sociological rather than an economic perspective Gallego-Álvarez et al., [31].

Other factors that may influence are the type of industry, industries such as banking or finance that are the object of this study may not really need gender differences in making important decisions for both their expansion and strategy, it's different in the beauty or fashion industry the views of women can be used as a basis for making business decisions that affect the performance and value of the company.

The results of this study are in line with Darmadi's [29] research which shows that the presence of women in the board room has a negative impact on the ROA and Tobin's Q of the company. Rose's [32] study examining whether female board representation affects Firm Value using a sample of organizations registered in Denmark during the period 1998-2001 also finds no significant relationship between Firm Value and female board representation. 
The Effect of Intellectual Capital on Company Value The results of the analysis show that intellectual capital has a significant effect on Firm Value as measured by Tobin's Q. This result is in accordance with hypothesis 4 which states that intellectual capital has a positive effect on Firm Value. With the acceptance of hypothesis 4 , it means that if a company is able to manage intellectual capital optimally so as to create a competitive advantage that is superior to other companies, the market will provide a higher assessment of the company. This is in line with the concept of Resources Based Theory (RBT).

This research is also in line with the research of Chen [21] and Randa \& Solon [33] which state that intellectual capital has a positive effect on Firm Value.

\section{The Effect of Financial Performance on Firm Value}

The results of the analysis show that financial performance has a significant effect on firm value. This result is in accordance with hypothesis 5 which states that financial performance has a positive effect on firm value. Based on the Signaling theory, the higher the profitability of a company, then this can be a positive signal for investors. Companies with high profitability can be interpreted by investors as a good prospect for the company in the future. Investors will be interested in investing by buying shares in the company, so that the share price increases and the company value will increase.

The results of this study are also in line with the research by Muliani [15] and Halimah [16] which shows that ROA has a significant effect on Tobins Q.

\section{The Effect of Gender Diversification on Firm Value through Financial Performance as an Intervening Variable}

The results of the analysis show that Gender Diversification has a insignificant effect on Firm Value through Financial Performance as an intervening variable. This is not in accordance with the initial hypothesis which states that Gender Diversification affects Company Value through Financial Performance, this hypothesis is based on stereotype theory and leadership theory which states that having women on the board of directors as decision makers will make better decision making because in The general perspective of women tends to emphasize their cognitive feelings more than men who tend to rely on logic, so that if the two work together it will make better decision making,

The Effect of Intellectual Capital on Firm Value through Financial Performance as an Intervening Variable

The results of the analysis show that Intellectual Capital has a significant effect on Firm Value through Financial Performance as an intervening or mediating variable, this proves that companies in the financial sector are able to generate Value Added from existing intellectual capital, the more efficient the use of capital, the more it produces added value for the company. until finally it affects the profitability of the company which has an impact on the better the value of the company for investors, this could be due to the increasingly aggressive use of technology in the financial transaction system for both banking companiesinsurance or securities companies that always update their systems to be more up-to-date and direct their customers to use technology that has been created and designed for the convenience of customers.

In accordance with the Resources Based Theory, a company that manages its resources efficiently will produce a competitive advantage, with this competitive advantage a company that is able to adapt to technology and the progress of the times is proven to be able to improve the company's financial performance, then for an investor, a company that is able to produce Good financial performance will certainly attract their interest to make the company an investment target, but in addition to financial performance, investors will certainly see the extent to which a company is able to manage their resources, with good resource management it is proven to be able to generate profitability which is also increasingly good, and will increase the value of the company in the eyes of investors, This is evidenced in this study that the better management of resources, in this case the efficient intellectual capital, will have an effect on the increasing financial performance of the company, so investors will judge that good management of the company will provide benefits for investors the company's market value will be better.

This study is also in line with the research of Bontis et al., [12] who concluded that, regardless of industry, structural capital development has a positive impact on business performance. Then if the financial performance is good, the company value will also be good.

\section{REFERENCES}

1. Petty, P., \& Guthrie, J. (2000). Intellectual capital literature review: measurement, reporting and management. Journal of Intellectual capital, 1(2):155-75.

2. Bontis, N. (2001). Assessing knowledge assets: a review of the models used to measure intellectual capital. International Journal of Technology Management, 3(1):41-60.

3. Ulum, I. (2017). Intellectual capital. Malang: UMM Press.

4. Belkaoui, A. R. (2003). Intellectual capital and firm performance of US multinational firms: astudy of the resource-based and stakeholder views. Journal of Intellectual capital. 4(2):215226.

5. Kusumastuti, S., \& Sastra, P. (2007). Pengaruh Board Diversity terhadap nilai perusahaan dalam perspektif corporate governance. (The impact of 
board diversity on firm value: Corporate governance perspectives). Jurnal Akuntansi dan Keuangan (Journal of Accounting and Finance), 9(2):88-98.

6. Rovers. (2010). Female Directors on Corporate Boards Provide Legitimacy to A Company. A Resource Dependency Perspective. Erasmus University Rotterdam (The Nethelands): 1-23.

7. Serenko, A., \& Bontis, N. (2013). Investigating the current state and impact of the intellectual capital academic discipline. Journal of Intellectual Capital. 14(4): 476-500.

8. Jumingan, J. (2009). Studi Kelayakan Bisnis: Teori dan Pembuatan Proposal Kelayakan. Jakarta: Bumi Aksara.

9. Reguera-Alvarado, N., de Fuentes, P., \& Laffarga, J. (2017). Does board gender diversity influence financial performance? Evidence from Spain. Journal of Business Ethics, 141(2), 337350.

10. Lee-Kuen, I. Y., Sok-Gee, C., \& Zainudin, R. (2017). Gender diversity and firms' financial performance in Malaysia. Asian Academy of Management Journal of Accounting and Finance, 13(1), 41-62.

11. Riahi- Belkaoui, A. (2003). Intellectual capital and firm performance of US multinational firms. Journal of Intellectual capital.

12. Bontis, N., Keow, W. C. C., \& Richardson, S. (2000). Intellectual capital and business performance in Malaysian industries. Journal of intellectual capital. 1(1): 85-100.

13. Solikhah, B. (2010). Implikasi intellectual capitalterhadap Financial performance, growth dan market value; Studi empiris dengan pendekatan simplistic specification. Simposium Nasional Akuntansi XIII Purwokerto, 2010.

14. Brammer, S., Millington, A., \& Rayton, B. (2007). The contribution of corporate social responsibility to organizational commitment. The International Journal of Human Resource Management, 18(10), 1701-1719.

15. Muliani, L. E., Yuniarta, G. A., AK, S., \& SINARWATI, N. K. (2014). Pengaruh kinerja keuangan terhadap nilai perusahaan dengan pengungkapan corporate social responcibility dan good corporate governance sebagai variabel pemoderasi. JIMAT (Jurnal Ilmiah Mahasiswa Akuntansi) Undiksha, 2(1).

16. Halimah, S. N., \& Komariah, E. (2017). Pengaruh roa, car, npl, ldr, bopo terhadap nilai perusahaan bank umum. JURNAL AKUNTANSI, EKONOMI dan MANAJEMEN BISNIS| e-ISSN: 25489836, 5(1), 14-25.

17. Smith, N., Smith, V., \& Verner, M. (2006). Do women in top management affect firm performance? A panel study of 2,500 Danish firms. International Journal of productivity and Performance management. 55(7):569-593.
18. Carter, D. A., Simkins, B. J., \& Simpson, W. G. (2003). Corporate governance, board diversity, and firm value. Financial review, 38(1), 33-53.

19. Siciliano, J. I. (1996). The Relationship of Board Member Diversity to Organizational Performance. Journal of Business Ethics. 15: 1313-1320.

20. Gordini, N., \& Rancati. E. (2017). Gender diversity in the Italian boardroom and firm financial performance. Management Research Review, 40(1):75-94.

21. Chen, M. C., Cheng, S. J., \& Hwang, Y. (2005). An empirical investigation of the relationship between intellectual capital and firms' market value and financial performance. Journal of Intellectual capital. 6(2):159-176.

22. Blau, P. (1977). Inequality and Heterogeneity. Free Press, New York.

23. Teg, W. T., \& Utami, W. (2016). Analisis Gender Diversity Dan Remunerasi Direksi Terhadap Kinerja Perusahaan. Jurnal TEKUN, 8(2):203221.

24. Sarwono, Jonathan. 2012. Path Analysis dengan SPSS: Teori, Aplikasi, Prosedur Analisis untuk Riset Skripsi, Tesis dan Disertasi. PT Elex Media Komputindo. Jakarta.

25. Baron, R. M., \& Kenny, D. A. (1986). The moderator-mediator variable distinction in social psychological research: Conceptual, strategic, and statistical considerations. Journal of personality and social psychology, 51(6), 1173.

26. Suliyanto, S. (2011). The effect of orientation learning on competitive advantage through innovation: study on small and medium enterprises. Business and Management Review, 1(7), 28-36.

27. Rosener, J. B. (1991). Ways Men and Women Lead, Debate, Harvard Business Review, 153/3.

28. Fondas, N., \& Sassalos, S. (2000). A different voice in the boardroom. Global Focus 12 (1): 1322.

29. Darmadi, S. (2013). Do woman in top management affect firm performance? Evidence from Indonesia; Emerald Group Publishing Limited, 13(3):288-304.

30. Wernerfelt, B. (1984). A ResourceBased View of the Firm, Strategic Manajement Journal, 5: 171180 .

31. Gallego-Álvarez, I., García-Sánchez, I. M., \& Rodríguez-Dominguez, L. (2010). The influence of gender diversity on corporate performance. Revista de Contabilidad-Spanish Accounting Review, 13(1), 53-88.

32. Rose, C. (2007). Does female board representation influence firm performance? The Danish evidence, Corporate Governance: An International Review, (15); 404-413.

33. Randa, F., \& Solon, S. A. (2012). Pengaruh modal intelektual terhadap nilai perusahaan. Jurnal sistem informasi manajemen dan akuntansi, 24-47. 